\section{Er tiden inne for å oppdatere seg på psykiske lidelser?}

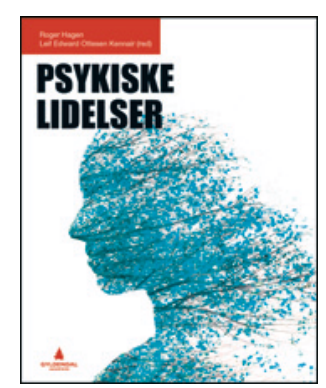

Roger Hagen, Leif Edward Ottesen Kennair Psykiske lidelser

311 s, tab, ill. Oslo: Gyldendal Akademisk,

2016. Pris NOK 499

ISBN 978-82-05-49026-0

Hva er en psykisk lidelse? Hvordan kan psykiske lidelser best utredes og diagnostiseres? Hvilke kunnskapsbaserte behandlinger er aktuelle? Dette er spørsmål de 2 redaktørene og 23 medforfatterne forsøker å besvare i bokens 14 kapitler.

De to første kapitlene handler om sykdomsforståelse og utredning, og de neste handler om tradisjonelle psykiske diagnoser. De siste kapitlene tar for seg søvnlidelser, spiseforstyrrelser, seksuelle forstyrrelser, rus, demens og personlighetsforstyrrelser. Redaktørene har som et ekstra mål å bygge ned tabuer. Bokens målgruppe er bred, fra mennesker som strever med psykiske lidelser, til forskere. En målgruppe som kan fremstå som en urealistisk spagat.

Språket flyter godt og gjør boken lett å lese. Det er noen få, men relevante tabeller og figurer. God bruk av pasienthistorier gjør i tillegg lesingen spennende og gir teorien mening. I noen av kapitlene brukes en dristig, men vellykket teknikk der den teoretiske teksten er støttet av innvevde pasienthistorier.

Bokens tittel gir ikke forventninger om en lærebok. Lærebokens oppbygning er likevel gjenkjennbar i de enkelte kapitlenes struktur. Innholdet gjenspeiler arbeidsmåter som forutsetter at terapeuten har gode tidsrammer. I drøftingene av diagnostiske utfordringer er det tatt hensyn til dagens situasjon og utviklingen fremover, som den viser seg i DSM-5 og ICD-11. Betydningen av terapeut-pasientrelasjonen er understreket, mens betydningen av kompetanse knapt er nevnt. Ulike behandlingsmetoder blir belyst med effektmål fra ferske studier og metastudier og med anbefalinger fra institusjoner som National Institute for Health and Care Excellence.

Som behandler i primærhelsetjenesten opplever jeg at boken gir oppdatert kunnskap om fenomenologi, diagnostisering og terapi i spesialisthelsetjenesten. Bildet av psykiske lidelser hos 19 av de 20 pasientene som får hele sin hjelp i førstelinjetjenesten, og de tilhørende mulighetene for forebygging, oppdagelse, mestringsstøtte og behandling er nesten fraværende. Et fravær som i rettferdighetens navn like mye kjennetegner fagfeltet, psykiske lidelser, som denne boken.

Med dette forbehold kan jeg anbefale boken til alle som ønsker en oversiktlig oppdatering av sin kunnskap for bedre å forstå og bistå mennesker med psykiske lidelser.

Ole Rikard Haavet

Fastlege, Lillestrøm Legesenter

\section{Revidert lærebok i transfusjonsmedisin}

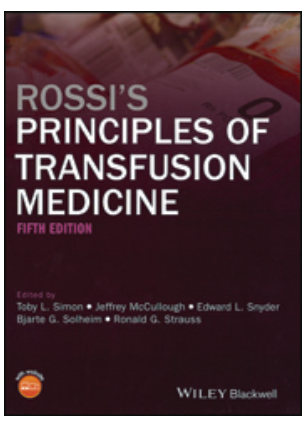

Toby L. Simon, Jeffrey McCullough, Edward L. Snyder et al, red. Rossi's principles of transfusion medicine 5. utg. 733 s, tab, ill. Chichester: WileyBlackwell, 2016. Pris GPB 218 ISBN 978-1-119-01299-3

25 år etter den første utgivelsen kommer en av de store lærebøkene i transfusjonsmedisin i 5 . utgave.

4 av 5 redaktører og 80 av 126 forfattere er fra USA. Én av redaktørene er norsk, og 4 norske kolleger er blant forfatterne.

Boken innledes med et detaljrikt, hovedsakelig teknologiorientert kapittel om transfusjonsmedisinens historie og nåværende megatrender. Så følger seksjoner om blodgivning, blodkomponenter og -derivater, aferese, transplantasjon, nye behandlingsmetoder, spesialisert klinisk praksis og bivirkninger.

Fokus er transfusjon i pasientbehandling. Seksjonen om blodgivning innledes med kapitlet «Patient Blood Management». Dette engelske begrepet bygger på utnyttelse av pasientens blodressurser og evidensbasert transfusjon. Andre forhold ved blodgivning gjennomgås godt, men problemkomplekset betalte blodgivere versus ubetalte avfeies med et par setninger.

Seksjonen om blodkomponenter og -derivater behandler også diagnostikk og vanlig klinisk transfusjon. Noen ville nok ha foretrukket å ha disse emnene i separate seksjoner.

Bokens største styrke er seksjonen om aferese, transplantasjon og nye behandlingsmetoder. Her bringes leseren inn i en rekke medisinske frontavsnitt.

Seksjonen om spesialisert klinisk praksis innledes med et velskrevet kapittel om obstetrisk transfusjon. Her beskrives også immunutløst trombocytopeni hos fostre og nyfødte. I det ellers gode kapitlet om hemolytisk sykdom hos fostre og nyfødte blir Rh-profylaksen og prenatal serologisk monitorering av blodtypeimmuniserte gravide stemoderlig behandlet. Alle mor-barn-immuniseringer burde vært samlet i ett kapittel som også beskrev profylakse og monitorering. Kapitlet om transfusjon ved traumer er up-to-date, men har få illustrasjoner.

Kapitlet om immunglobuliner omhandler den sterkeste drivkraften i nåtidens transfusjonsmedisin. Mye av forbruket hviler på svak evidens, men kapitlet problematiserer dette i liten grad.

Teksten er satt med nokså små typer, og de fleste referansene må hentes på nett. Dette sparer plass, men gjør boken tung å lese og å bruke som referansekilde. Mange kapitler ville tjent på færre ord og flere illustrasjoner.

Denne boken er mer et supplement til Mollisons evigunge Blood Transfusion in Clinical Medicine enn en konkurrent. Den er fortsatt USA-dominert, men har mye å tilby transfusjonsmedisinere og transfusjonsinteresserte klinikere også $\mathrm{i}$ andre land.

Hans Erik Heier

Professor emeritus, Universitetet i Oslo 